\title{
LOUVAIN NATURAL RADIOCARBON MEASUREMENTS V
}

\section{E. GILOT}

Department of Nuclear Chemistry, University of Louvain, Louvain, Belgium

The measurements reported in this list were made in the Louvain $\mathrm{C}^{14}$ lating laboratory in 1966. Sample preparation, counting procedure and calculation method are described in the previous lists. Ages are calculated on the basis of a $\mathrm{C}^{14}$ half life of $5570 \mathrm{yr}$ (Godwin, 1962). Errors, including the experimental standard deviation of the counting rate of the background, of the modern standard and of the unknown sample, are expressed by $1 \sigma$ (Crèvecoeur and others, 1959).

Thanks are due to Professor P. C. Capron for his help in many constructive discussions. We wish to acknowledge the assistance of F. Frix in the operations of the laboratory, and of G. Michotte in the maintenance of electronics. The description of each sample is based on information provided by the submitters. Financial support was provided by the Institut Interuniversitaire des Sciences Nucléaires, Brussels.

\section{SAMPLE DESCRIPTIONS}

I. GEOLOGIC SAMPLES

\section{Valley of the Lienne series}

Peat from marshy alluvial plain of river Lienne, Prov. of Luxembourg, Belgium. Bogs of valley of the Lienne show differences between evolution of vegetation of lower valleys and that of the High Plateaus (Gullentops and others, 1966). Pollen analysis by W. Mullenders, Univ. of Louvain, Lab. of Palynology. Coll. 1965 and subm. by W. Mullenders.

\section{Lv-271. Lierneux I}

$2190 \pm 160$

Peat from Hierlot $\left(50^{\circ} 18^{\prime} 36^{\prime \prime} \mathrm{N}\right.$ Lat, $5^{\circ} 46^{\prime} 16^{\prime \prime}$ E Long) near Lierneux, alt $340 \mathrm{~m}$. Taken from peat layer, $15 \mathrm{~cm}$ thick, in steep bank of rivulet of Hierlot, $1 \mathrm{~m}$ below surface of grassland. Pollen analysis indicates beginning of Sub-Atlantic period.

\section{Lv-272. Chevron I}

$2600 \pm 130$

Fibrous peat from Chevron (50 $21^{\prime} 50^{\prime \prime} \mathrm{N}$ Lat, 5" 49' 02" E Long) at foot of northern slope of Plateau des Tailles, alt $260 \mathrm{~m}$. From 37.0 to $42.5 \mathrm{~cm}$ below ground surface. Palynologically this level is situated slightly above Sub-Boreal-Sub-Atlantic transition. Date agrees with others of this transition in the Ardennes: 814 B.c. at Baraque Michel (Dricot, 1960), 820 в.C. and 840 в.c. at Grand Passage (Lv-59 and Lv-60, Louvain II). 
Lv-273. Chevron I

Fibrous peat from same site, 52 to $58 \mathrm{~cm}$ depth. At this level comes Atlantic-Sub-Boreal transition, usually dated 1600 to 2000 B.c.

\section{Lv-274. Chevron I}

$7630 \pm 170$

Peaty clay in bottom of peat layer, 75 to $83 \mathrm{~cm}$ depth. Sample corresponds to Boreal-Atlantic transition, estimated age 5500 to 6000 B.C.

\section{Valley of the Nethen series}

Dates in correlation with the study of the formation of the alluvial plain of the Nethen river, Prov. of Brabant, Belgium (Mullenders and others, 1966). Coll. 1965 by J. Lorent and subm. by F. Gullentops, Univ. of Louvain, Lab. of Geol. Pollen analysis by W. Mullenders.

\section{Lv-276. Tourinnes la Grosse I}

$2110 \pm 90$

Humic matter from Tourinnes la Grosse $\left(50^{\circ} 46^{\prime} 54^{\prime \prime} \mathrm{N}\right.$ Lat, $4^{\circ} 46^{\prime}$ 03" E Long), from calcareous peat layer, ca. $20 \mathrm{~cm}$ thick, at $120 \mathrm{~cm}$ below ground surface in bank of Nethen river, alt $75 \mathrm{~m}$. Date agrees with pollen analysis: beginning of Sub-Atlantic period. Comment: date only includes soluble humic matter, because solid residuum after $\mathrm{NaOH}$ leach was insufficient.

\section{Lv-277. Nethen I}

$4260 \pm 150$

Peat from Nethen $\left(50^{\circ} 46^{\prime} 54^{\prime \prime} \mathrm{N}\right.$ Lat, $4^{\circ} 39^{\prime} 38^{\prime \prime} \mathrm{E}$ Long) in allurial plain of Nethen river, alt $32 \mathrm{~m}$. Peat layer, $175 \mathrm{~cm}$ thick, is covered by $380 \mathrm{~cm}$ of clayey alluvium and peaty clay. Sample from 410 to $425 \mathrm{~cm}$ below ground surface. Pollen diagram shows at this level end of Atlantic period. Date agrees well with other $\mathrm{C}^{14}$ dates for this period.

\section{Lv-279. Nethen I}

$6350 \pm 180$

Peat from same site as Lv-277, 510 to $520 \mathrm{~cm}$ depth. Boreal-Atlantic transition. According to pollen analysis, date seems too young. Transition is generally dated 7500 to 7800 B.P. Comment (W.M.): contamination by younger material is possible because inadequate boring instruments; however other dates for same level at Baraque Michel are 6720 \pm 120 and $6740 \pm 70$ (Schumacker, 1961). Thus palynological indications for this transition may be placed a little too high in Belgium.

\section{Lv-280. Dilsen}

$3570 \pm 110$

Wood (Quercus, id. by J. Heim) from Dilsen $\left(51^{\circ} 02^{\prime} 15^{\prime \prime} \mathrm{N}\right.$ Lat, $5^{\circ} 44^{\prime} 30^{\prime \prime}$ E Long), Prov. of Limburg, Belgium, alt $34 \mathrm{~m}$. Imbedded in humic clay horizon at ca. $3 \mathrm{~m}$ below ground surface. Coll. 1965 by E. 
Paulissen, Univ. of Louvain, Lab. of Geol.; subm. by F. Gullentops. Pollen analysis, by W. Mullenders, indicates beginning of Sub-Boreal period. Date agrees with expectations (Paulissen, 1966).

\section{Lv-284. Meeswijck I}

$5210 \pm 130$

3260 B.C.

Peat and wood twigs from Meeswijck $\left(51^{\circ} 00^{\prime} 20^{\prime \prime} \mathrm{N}\right.$ Lat, $5^{\circ} 43^{\prime} 35^{\prime \prime}$ E Long), Prov. of Limburg, Belgium, alt $35 \mathrm{~m}$. Peat layer, $45 \mathrm{~cm}$ thick, at ca. $3 \mathrm{~m}$ below ground surface. Sample taken at 32 to $35 \mathrm{~cm}$ depth in peat layer. Coll. 1965 and subm. by W. Mullenders. Pollen diagram shows at this level second part of Atlantic period, with classical elm fall. Date agrees closely with other dates of this level in Belgium, Netherlands, Germany and England.

\section{ARCHAEOLOGIC SAMPLES}

\section{Neuchatel Lake series, Switzerland}

$$
2890 \pm 110
$$

Lv-270. Pirogue of Bevaix

Wood from prehist. pirogue, $8 \mathrm{~m}$ long, found in Neuchatel lake at Le Moulin $\left(46^{\circ} 55^{\prime} \mathrm{N}\right.$ Lat, $6^{\circ} 49^{\prime} \mathrm{E}$ Long) near Bevaix, Canton of Neuchatel, Switzerland. Coll. 1879 by M. Borel; subm. by P. Grandjean, Cantonal Archaeol. Mus. of Neuchatel. The pirogue is correlated with known stations of Bronze age (Vouga, 1943). $\mathbf{C}^{14}$ date agrees with archaeol.

\section{Lv-269. Roman oar}

$$
1730 \pm 100
$$

Wood from oar-rudder found in Neuchatel lake near Bevaix $\left(46^{\circ}\right.$ $55^{\prime} \mathrm{N}$ Lat, $6^{\circ} 50^{\prime} \mathrm{E}$ Long), Canton of Neuchatel, Switzerland. Subm. by P. Grandjean. The oar, kept in Cantonal Archaeol. Mus. of Neuchatel, was assumed to be of Roman age. $\mathrm{C}^{14}$ date confirms estimate.

\section{Lv-209. La Tène}

$1080 \pm 90$

Wood from wall of wooden construction at La Tène $\left(47^{\circ} 15^{\prime} \mathrm{N}\right.$ Lat, $7 \circ 00^{\prime}$ E Long) along Thièle river, near Préfargier, Canton of Neuchatel, Switzerland. Subm. by P. Grandjean. Comment (E. Borel): in the first archaeol. analysis, construction was correlated with the prehist. site of La Tène, but a new study by J. P. Jecquier, Cantonal Archaeol. Mus. of Neuchatel, ascribes it to time of Charlemagne. $\mathrm{C}^{14}$ date agrees with second estimate.

\section{Lv-217. Robberg Cave, S. Africa}

$2660 \pm 150$

710 B.c.

Bones from Wagenaar's Cave (34 $05^{\prime} \mathrm{S}$ Lat, $23^{\circ} 22^{\prime} \mathrm{E}$ Long) in Robberg Peninsula Reserve at Plettenberg Bay, Cape Province, South Africa. Cave was occupied until recently by the "Strandloopers". It contains a cultural deposit, $17 \mathrm{ft}$ thick, of Late and Middle Stone Age (Ins- 
keep, 1965). Dated skeleton, found in upper level, dates end of deposit. Coll. 1964 by E. L. Boné, Univ. of Louvain, Lab. of Paleontology, and Q. B. Hendey, South African Mus. of Cape Town; subm. by E. L. Boné and R. R. Inskeep, Univ. of Cape Town. Comment: bones were treated with cold normal $\mathrm{HCl}$ and the insoluble part used for dating.

\section{Ordona series, Italy}

Charcoal from Ordona (41 $18^{\prime} \mathrm{N}$ Lat, $15^{\circ} 37^{\prime} \mathrm{E}$ Long), Prov. of Foggia, Italy. Series dates occupation of ancient Roman colony at Herdoniae (Mertens, 1964; 1965). First part was published in Louvain III. Coll. 1965 and subm. by J. Mertens, Univ. of Louvain, Archaeol. Inst.

\section{Lv-218. Ordona}

$1660 \pm 90$

Charcoal from "chapel" at $\mathrm{E}$ of Temple A. The building, situated near the forum, must have been destroyed in beginning of 4th century.

\section{Lv-222. Ordona}

$2210 \pm 100$

Charcoal from Excavation XLVI under Wall 19, $4 \mathrm{~m}$ depth. Date agrees with archaeol. estimate.

\section{Lv-225. Ordona}

Charcoal from Excavation XVIII, under Roman road, $1.35 \mathrm{~m}$ depth. From same site as $\mathrm{Lv}-177$ and $\mathrm{Lv}-178$, dated A.D. $50 \pm 80$ and A.D. $20 \pm$ 100 (Louvain III).

\section{Lv-226. Ordona}

$2020 \pm 90$

Charcoal from Excavation XLV under street of ancient city, $1.70 \mathrm{~m}$ depth. Date agrees with archaeol.

\section{Lv-281. Ordona}

Charcoal from lower layer of amphitheatre, 1. $20 \mathrm{~m}$ depth. Dates pre-Roman city. Date agrees with archaeol. estimate.

\section{Lv-283. Ordona}

$$
1530 \pm 120
$$

Charcoal from Ordona from a pit arranged in a shop along SE side of forum. Date gives proof of the time of occupation of Phase 2 in this construction.

\section{Lv-26. Beerlegem}

$1550 \pm 90$

Wood from wooden bottom of Merovingian grave at Beerlegem $\left(50^{\circ} 54^{\prime} 20^{\prime \prime} \mathrm{N}\right.$ Lat, $3^{\circ} 43^{\prime} 30^{\prime \prime} \mathrm{E}$ Long), Prov. of Eastern Flanders, Belgium. Coll. 1957 by Roosens, Service des Fouilles, Brussels; subm. by 
J. Mertens. Grave is archaeol. dated, according to funeral goods, to first half of 7 th century (Roosens, 1959).

\section{Lv-195. Marchin}

A.D. 1190

$760 \pm 100$

Wood from fortified farm of Laître $\left(50^{\circ} 27^{\prime} 42^{\prime \prime} \mathrm{N}\right.$ Lat, $5^{\circ} 15^{\prime} \mathrm{E}$ Long) at Marchin, Prov. of Liege, Belgium. From a beam, part of original construction of a tower, above a loophole, at $2 \mathrm{~m}$ above present level of street. Coll. 1964 and subm. by J. E. Opsomer, Univ. of Louvain. This fortified farm constructed on foundations of a Roman villa; a 12thcentury date for the building of the tower was expected. Historic study continues.

\section{Lv-188. Houtberg I}

$1990 \pm 120$

40 B.c.

Charcoal from Tontelange (49 $42^{\prime} 29^{\prime \prime} \mathrm{N}$ Lat, $5^{\circ} 47^{\prime} 50^{\prime \prime}$ E Long), Prov. of Luxembourg, Belgium. Found with human bones in necropolis of La Tène III, at $50 \mathrm{~cm}$ depth under Grave B, Sq. V. Coll. 1959 and subm. by M. Coûteaux, Univ. of Louvain, Lab. of Palynology. Potsherds were determined and archaeol. dated by P. Bonenfant, Service des Fouilles, Brussels, as middle of lst century B.C., probably just before Roman influence (Bonenfant, 1961). A pot from another grave of same site contained pollen with 40 percent of Fagus (Coûteaux, 1961)

\section{Lv-285. Nadrin}

A.D. 1110

$\mathbf{8 4 0} \pm \mathbf{1 0 0}$

Wood from Ollomont $\left(50^{\circ} 03^{\prime} \mathrm{N}\right.$ Lat, $5^{\circ} 06^{\prime} \mathrm{E}$ Long $)$ at Nadrin, Prov. of Luxembourg, Belgium. Taken from medieval masonry at height of ca. $7 \mathrm{~m}$ in steeple of church. Coll. 1966 and subm. by R. Lemaire, Univ. of Louvain, Appl. Sci. Inst. $\mathrm{C}^{14}$ date confirms archaeol. estimate: between A.D. 1050 and 1130 (Genicot, 1966).

Date Lists:

\section{REFERENCES}

Louvain II Deumer, Gilot, Capron, 1964

Louvain III Gilot, Ancion, Capron, 1965

Bonenfant, P. P., 1961, Sépultures trévires à Tontelange: Archaeologia Belgica, no. $57,26 \mathrm{p}$.

Coûteaux, M., 1961, Recherches phytosociologiques et historiques sur quelques forêts de Gaume: thesis, Louvain Bot. Inst., $126 \mathrm{p}$.

Crèvecoeur, E. H., Vander Stricht, A., Capron, P. C., 1959, Precision of the dating method. Standardization of the calculation of the errors and the maximum age in the $\mathrm{C}^{14}$ method: Acad. Royale Belgique Bull. Cl. Sci., v. 45, p. 876-890.

Deumer, J. M., Gilot, E., Capron, P. C., 1964, Louvain natural radiocarbon measurements II: Radiocarbon, v. 6, p. 160-166.

Dricot, E. M., 1960, Recherches palynologiques sur le plateau des Hautes Fagnes: Soc. Royale de Bot. Belgique Bull., v. 92, p. 157-196.

Genicot, L. F., 1966, La Chapelle Sainte Marguerite à Ollomont: Ardenne et Famenne, v. 1, p. 5-51.

Gilot, E., Ancion, N., Capron, P. C., 1965, Louvain natural radiocarbon measurements III: Radiocarbon, v. 7, p. 118-122.

Godwin, H., 1962, Half-life of radiocarbon: Nature, v. 195, no. 4845, p. 984. 
Gullentops, F., Mullenders, W., Schaillée, L., Gilot, E., Bastin-Servais, Y., 1966, Observations géologiques et palynologiques dans la vallée de la Lienne: Acta Geographica Lovaniensia, v. 4, p. 192-204.

Inskeep, R. R., 1965, Univ. of Cape Town excavations at Plettenberg Bay: Scientifica South Africa, v. 2, no. 12.

Mertens, J., 1964a, Richerche archeologiche ad Ordona. Rapporto provvisorio sulla campagna del 1962/63: Notizie dei Scavı, v. 16, p. 1-29.

1964b, Recherches archéologiques à Ordona (Anticue Herdoniae en Apulie, Italie). Rapport sur les travaux entrepris en 1962 et 1963: Accad. Naz. dei Lincei Rendiconti, v. 19, p. 110-116.

1965, Ordona, I Rapport provisoire sur les travaux de la mission belge en 1962/63 et 1963/64: Etudes de Philologie, d'Archéologie et d'Histoire Ancienne, v. 8,33 p., 36 pl.

Mullenders, W., Gullentops, F., Lorent, J., Coremans, M., Gilot, E., 1966, Le remblaiement de la vallée de la Néthen: Acta Geographica Lovaniensia, v. 4, p. 169 181.

Paulissen, E., 1966; Eerste resultaten van een morfologisch onderzoek in de vallei van de Maas in belgisch Limburg: Acta Geographica Lovaniensia, v. 4, p. 114-128.

Roosens, H., 1959, Houten VIIe eeuwse grafkamer met vrouwensieraden te Beerlegem: Archaeologia Belgica, v. 49, p. 138-157.

Schumacker, R. 1961, Etude d'une tourbe à scheuzeria palustris dans les couches inférieures des dépôts de la Fagne Wallonne: Soc. Royale des Sci. de Liège Bull. no. 11-12, p. 1-16.

Vouga, D., 1943, Préhistoire du pays de Neuchatel des origines aux Francs: Soc. Neuchateloise des Sci. Nat. Mem., v. 7, 253 p., 34 pl. 